\title{
Studies in the Vocabulary of the Byelorussian Translations of the Bible
}

BY

\section{MOSHÉ ALTBAUER}

The Byelorussian translation from the Hebrew of nine books of the Bible, dating from the late 15th or early 16th century, preserved in manuscript Codex 262 in the Central Library of the Lithuanian Academy of Sciences in Vilna, offers much interesting material for the history of Byelorussian lexicology, and of East Slavonic lexicology in general. It is the purpose of the present article to provide a few examples of this from this manuscript in a comparative context, la) A fioly puskajut' zapach (S. of S., VII, 14; see fig. 1). In the King James Bible the phrase is translated as 'The mandrakes

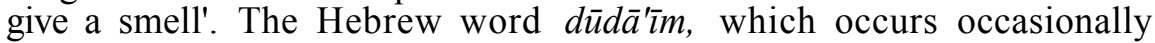
in the Bible (Gen. XXX, 14-16; S. of S. VII, 14) has been identified as the name of the plant Mandrago officinalis of the genus Shlancea, having light-blue and greenish-yellow flowers. ${ }^{1}$ The Septuagint, and the Vulgate which follows it, use hoi mandragorai and mandragorae respectively.

The translator of the Song of Songs in Codex 262 preferred the name taken from the vernacular, fioly, to the bookish borrowing from the Greek, unlike the editor of the first printed Slavonic Bible of 1582 (the 'Ostrog Bible'), based, as is well-known, on earlier Slavonic translations. There we read mandragore daša vonju. Similarly, later, in the so-called Synodal Bible there is mandragory daša vonju; even the recent Russian version, published by the American Bible Society, has mandragory uže pustili blagovonie. The Polish Catholic translator Jakub Wujek (1599), who followed the Vulgate, also used the word mandragora, as did the editors of the most recent Polish Catholic Bible, the so-called Biblia Millenii (Poznan, 1965). The Polish Protestant version of 1632 , on the other hand, has polne jabtuszka, probably following pěкná jablečka of the Czech Kralická Bible of 1613. In the earliest Polish manuscript Bible of the 15th century (the so-called Biblia królowej Zofii) the page on which Gen. XXX, 14 would normally be found is missing. The Croatian Catholic Bibles - the earliest version by Daničić and the most recent one published in Zagreb in 1968 - have respectively

1. J. Löw, Die Flora der Juden, III, Vienna, 1924-35, pp. 365-68. 


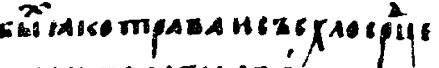
MOE NAESATH AZ GBMH SBTHM

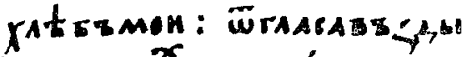

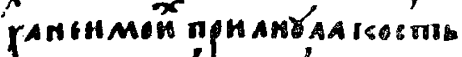
mon mt armosar : posers

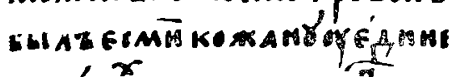

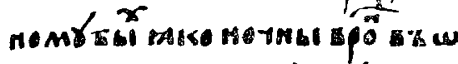
"4

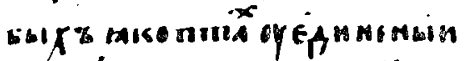

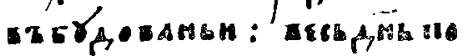

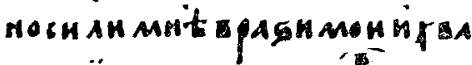

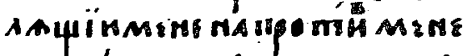

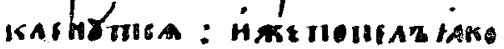

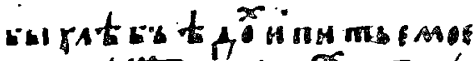

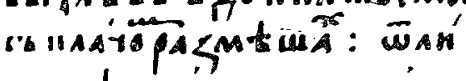

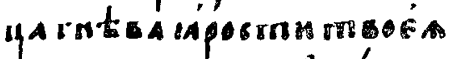
lake B'b

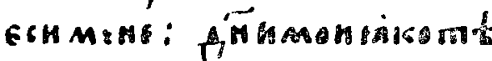

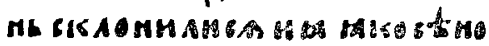

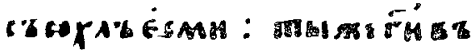

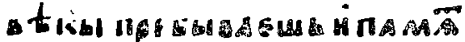

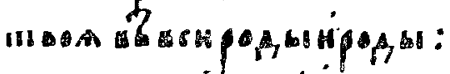

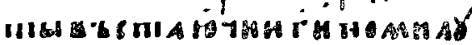
SUS6 б

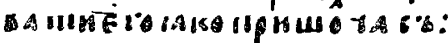

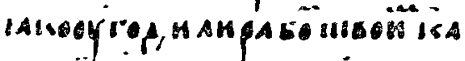
Mimíf

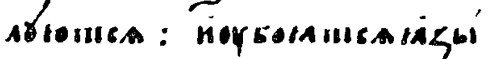

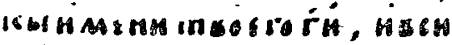
IP̈H

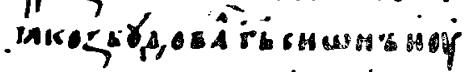

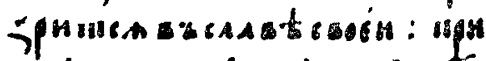

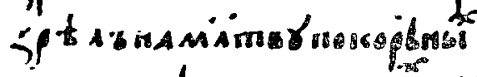
ที丶万

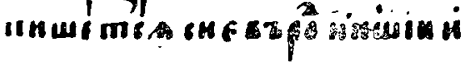

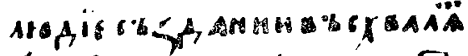

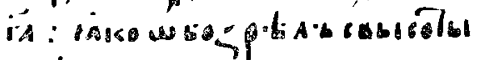

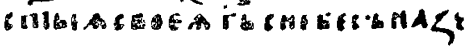
AAAIO IIPH

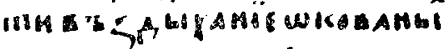

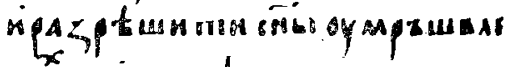

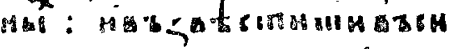
suntisiso

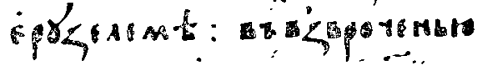

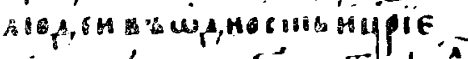

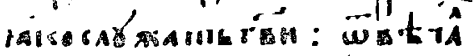

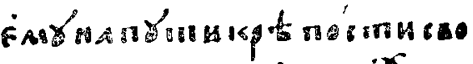

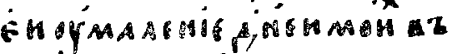

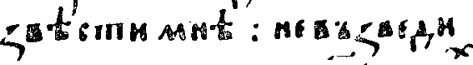

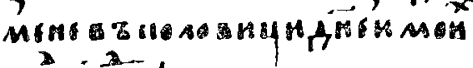

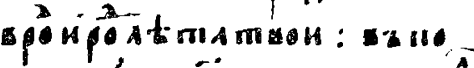

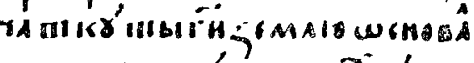

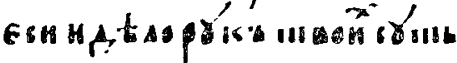

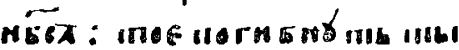

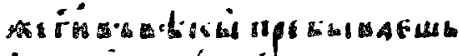

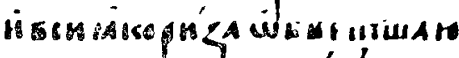
TIS : MAALO

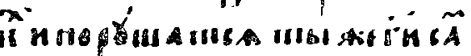

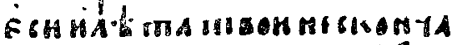
1018BGA: Sค่

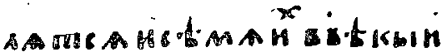
SBPÁB̈BEA:

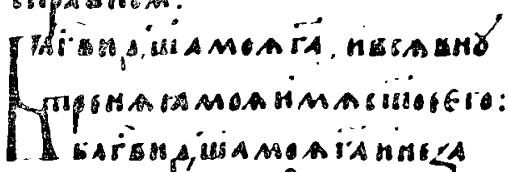

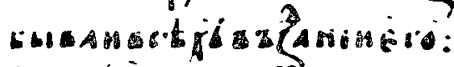

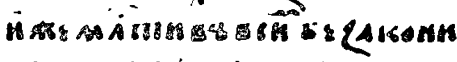
6n mor

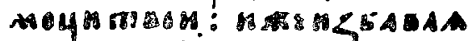
F

fig. 1. Codex 262 of the Central Library, the Lithuanian Academy of Sciences, Vilna. Folio $85 v$. S. of S. VI-VII, 6. 


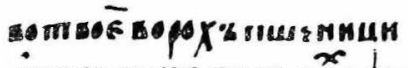

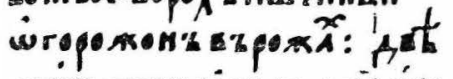

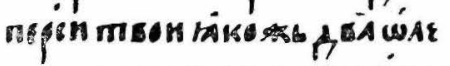
MAUTA SAM ZNBLY AAMGḦNGL:

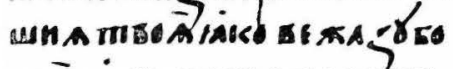

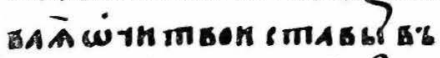

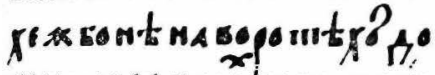

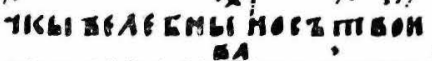

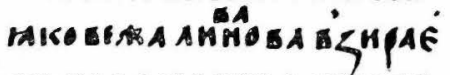
IISMAPANACKOL : TONOEA

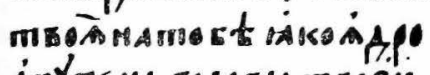
AIIVTE Y TO ROAO

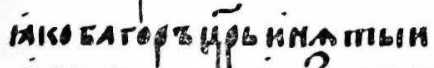

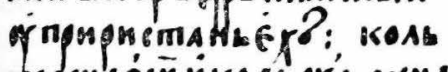

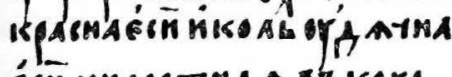
ЁЕИ MHAOCTMAA SZ ISSTA

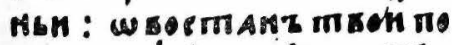

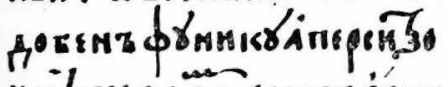

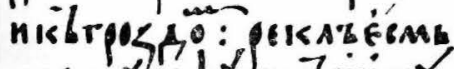

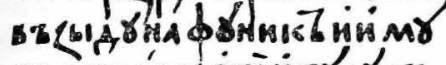

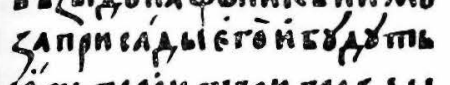

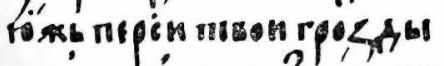

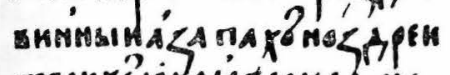

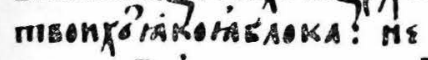

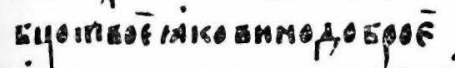

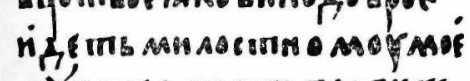

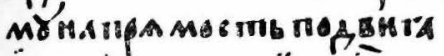

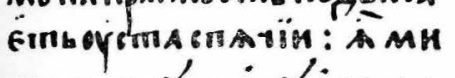
AESUINOMV MOSMY SINAMA AATISAETE: TOMAMMMNAO CUINLINMOH ESI HA ARZNA,

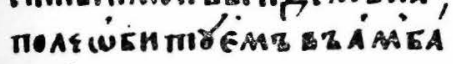

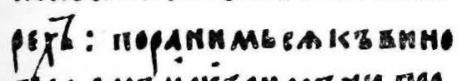

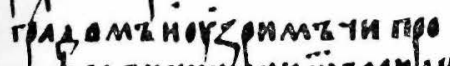

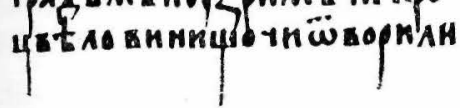

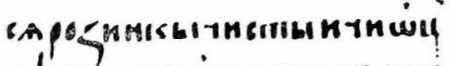
- ТанмAPISTPAMU maMt

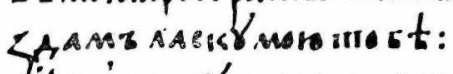

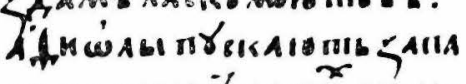

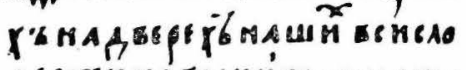

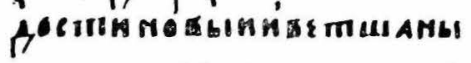

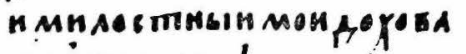
AAÉrMninOEt : кmisu

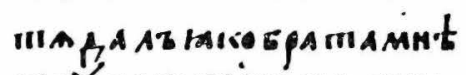
ezeryeare reperimatrism!

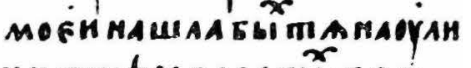

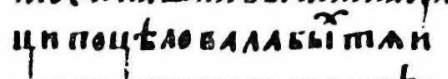
mist he TAMnAN EGIMMt:

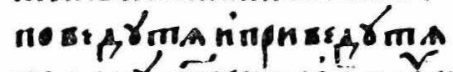

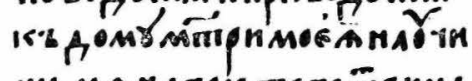

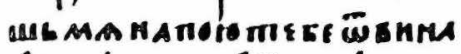

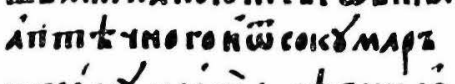

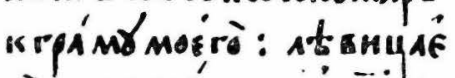

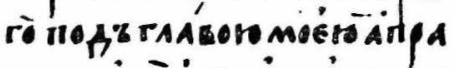

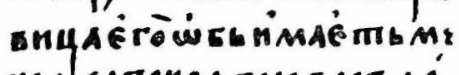

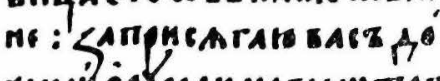

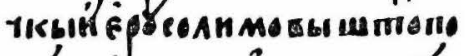

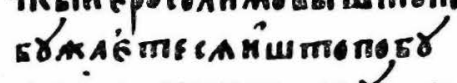

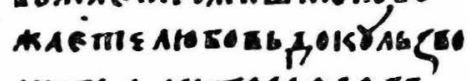
AKTIL: ISOTIOPAABA ET

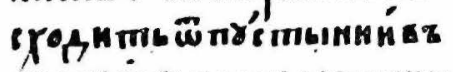

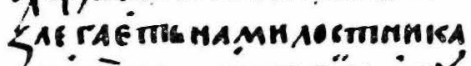

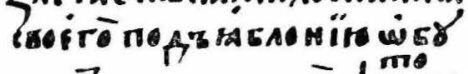

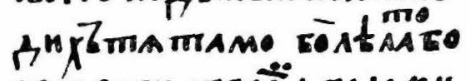
Н МАTK II ВOÄ: ПOAOKN

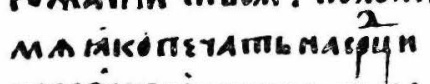

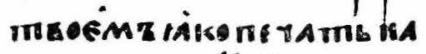
MULYYИ TISO

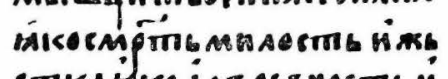

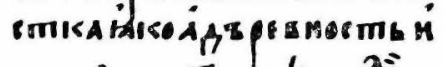

$$
\begin{aligned}
& \text { نnimamb roata póni } \\
& \text { ANHपATIGOÁ: }
\end{aligned}
$$

fig. 2. Codex 262. Folio 67. Psalms CI, $5-\mathrm{C \Pi ,} 4$. 
mandragore puštaju miris and mandragore šire miris. In the latest Lithuanian Catholic Bible, translated by Archbishop Juozapas Jonas Skvireckas, mandragore is retained in Gen. XXX, 14, but in the Song of Songs the Lithuanian expression kukeliai duoda kvapa unexpectedly appears.

Sreznevskij in his Materialy dlja slovarja drevnerusskogo jazyka does not include either fioly or mandragory, but the second word is recorded by both Dal' and Vasmer in their dictionaries. ${ }^{2}$

One can thus assume that fioly in Codex 262 is the first deliberate use of this word in Byelorussian, and in East Slavonic languages in general. A similar expression in Polish, written variously as fiotek, fijolek and fijatek was known from the 15th century with the connotation viola ododrata L. It corresponds to the later Russian loan word from Polish fialka and fiol', and to the Ukrainian fijalka, fijalok (Cheirantus cheiri). No use was made, however, of these expressions in the Bible translations into these two East Slavonic languages.

Finally it should be noted that, like the Jewish translator of the Song of Songs into Byelorussian in Codex 262, the Yiddish translation

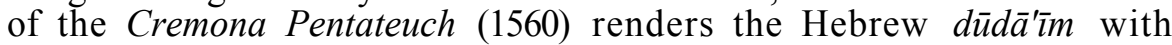
the expression $w j j^{\prime} l n$, corresponding to the New High German Veilen, which in its turn is derived from the High German viol, viole, and the Middle Latin fiola. It is possible to find more, similar lexical and textual analogies between the Byslorussian version of Codex 262 and the older traditional translations of the Bible into Yiddish ${ }^{3}$ (see below).

The use of vernacular expressions in preference to the 'bookish' borrowings, and in particular hellenisms, is a characteristic feature of the language of Codex 262. The following are a few examples, also taken from the field of botanical and zoological terminology,

1b) In place of vjazanie stakti (S. of S. I, 13) of the Ostrog Bible, later repeated in the Synodal Bible, corresponding to the Septuagint apodesmos tēs staktess from the Hebrew tseror hammor, the translator of the Byelorussian codex 262 used the expression hruda pižma. ${ }^{4}$ In Skaryna the same expression is translated as svjazok mirry, while the new Russian translation has mirrovyj puček. 1c) Instead of okrida (Eccl. XI, 5) as in the Ostrog Bible, corresponding to the Greek he akris and Hebrew hāgāb, Codex 262 has the word kobylica, a term encountered in many Slavonic languages signifying 'locust' (in this instance it means the genus Calliptamus palestinensis Rammae). Skaryna translates akris by kobylka, and the new Russian version uses the word kuznečik. In the Synodal Slavonic version, of

2. V. Dal', Tolkovyj slovar' russkogo jazyka, StP., 1903, II, p. 269; M. Vasmer, Etimologičeskij slovar' russkogo jazyka, II, Moscow, 1967, p. 569.

3. See M. Altbauer, Some Methodological Problems in Research of the East Slavic Bible Translations (Vilnius Codex 262) (A paper read at the VI Intern. Congress of Slavis'ts), Jerusalem, 1968. (On the word gim in those translations.)

4. On the origin and meaning of the word pižma see Vasmer, op. cit., III, Moscow, 1971, p. 259.

5. On this meaning of kobylica see A. Brückner, Stownik etymologiczny jezyka polskiego, Warsaw, 1957, p. 241 (under the entry kobyta); also Vasmer, op. cit., II, p. 269, also under kobyla). 
more recent date than the Ostrog Bible, the Greek word is replaced by pruzi, a plural form, whereas both in the Hebrew original and the Septuagint the word is in the singular. The word pruzi, or prußi, for the Hebrew 'arbe, which is the general name for 'locust' in the Bible, is found in several East Slavonic translations of the Psalms (CVIII, 23). It is written variously as prozi (Pogodin psalter), prougii (13th century Simonovski Psalter), prouzi, proužie, proug, etc. . In Byelorussian versions prußi is found in Codex 262, and pruzi in Skaryna. The new Russian version has the word saranča: gonjal menja kak saranču.

1d) Another zoological name, which occurs in Psalm CI, 7, is of considerable interest both for the history of Byelorussian lexicology and because of the light it sheds on the translation techniques of the author of Coclex 262. The Hebrew word qa'àat occurs five times in the Old Testament. In the Septuagint it is fairly consistently translated as pelekan: ōmoiōten pelekani erēmikō (Ps. CI, 7). In the corresponding passage the Vulgate has the word pellicanus: similis jactus sum pellikano solitudinis; in other places, however (Lev. XI, 18; I. XXXIV, 11; Zeph. II, 14), a different word is used: onocrotalus. Old Church Slavonic versions have the word nejesyt': upodobich się nejessyti pustyněi (Psalt. Sinaiticum); neQsyti (Psalt. Boloniense); nejasyti (Pogodin Psalter), etc. One of the manuscripts has nejesyti in the text with pellikanovi as a marginal note. Skaryna's version, upodobich sja nejasyti pustynnorau, is in accordance with the East Slavonic tradition. The word pelikan is used in new Slavonic Bible translations, e.g. in the recent Russian version: ja upodobilsja pelekanu na pustyni; and the Polish Biblia Millenii: jestem podobny do pelekana $z$ pustyni. The new Croat version has the word čaplja instead: slican sam čaplji $u$ pustynji.

The term $q \bar{a}^{\prime} \bar{a} t$ was understood in a completely different manner by the author of the Byelorussian Codex 262. Being well versed in Hebrew Biblical exegesis, 7 he knew that the word in question had nothing to do with a 'pelican'. All Hebrew exegetes, past and present, agree that $q \bar{a}^{\prime} \bar{a} t$ belongs to a group of nocturnal birds of prey. Some members of this group devour their prey (e.g. field mice) whole and afterwards disgorge the skin and bones. This is reflected in the etymological link between the noun $q \bar{a}^{\prime} \bar{a} t$ and the verb derived from the same stem, $q \bar{\imath}$ — 'to disgorge, vomit'. Recently $q \bar{a}$ ' $\bar{a} t$ has been identified with a bird of the family Strigidae, to which also belongs the Biblical kōs (Athene noctua, according to the ornithologists) mentioned in the same Psalm verse, and called in the Septuagint nuktikorax. Both $q \bar{a}^{\prime} \bar{a} t$ and $k \bar{o} s$ are regarded by the Jews as unclean and forbidden to be eaten (cf. Lev. XI, 17; Deut. XIV, 17). In the same category is also included the bat (Hebrew 'atalef; cf. Lev. XI, 19)

6. Amfllochij, Drevne-slavjanskaja psaltyr' XIII veka, Moscow, 1874-9, II, p. 293.

7. On the question of the knowledge of Hebrew exegesis by the author of Codex 262 see notes 3 and 16 . 
which, according to the Jewish biblical and post-biblical tradition, is considered to be a bird. All this must have been familiar to the author of Codex 262. Accordingly, he did not follow the traditional Greek and Slavonic biblical versions, but translated the Hebrew $q \bar{a}^{\prime} \bar{a} t$ by kožan, which is Byelorussian for 'bat'. ${ }^{8}$ In fact the whole verse 7 of Psalm CI in Codex 262 is differently worded than in other Slavonic texts: roven byl esmi kožanu uedinennomu, bych jako nočny voron $v$ obchoženii (see fig. 2).

Thus the author of Codex 262, who was hardly an ornithologist, in translating the Hebrew word $q \bar{a}$ 'a $t$, chose the name of the 'bird' of prey which must have been familiar to him from everyday Byelorussian. Moreover he did not follow the established Slavonic tradition in another point, and used the adjective uedinennomu ('solitary') instead of pustyněi or pustynnomu ('desert'). The possibility of the existence of another meaning of the word kožan, closer to the Hebrew $q \bar{a}^{\prime} \bar{a} t$, cannot be definitely excluded at this stage. If it exists, however, it has yet to be discovered.

Again we find a parallel between the translation of Codex 262 and the old translation into Yiddish; the word $q \bar{a}^{\prime} \bar{a} t$ is translated by a Yiddish word which means a bird of prey (as for instance tol or dol corresponding to the New High German toll).

1e) Instead of ot sredy skumen (Ps. LVI, 5) as in earlier East Slavonic versions, corresponding to the Greek ek mesou skumon, Codex 262 uses the native expression ot jadei lvovych. The word $\mathrm{jad}^{\prime}$ is synonymous with synove, as can be seen from the expression jad' tula svoego (Lam. Ill, 13) in the manuscript Bible of 1499, to which the corresponding text in Codex 262 is synov tula svoego (for Hebrew bene 'ašpātō, which is translated in the Septuagint as ious faretras autou). Skaryna uses the Greek expression with the addition of l'vovych: ot sredy skimen l'vovych. It should be noted, however, that in other places in Codex 262 the hellenism is used. Thus in Psalm CIII. 21 one finds skumen l'vovyi, and again in Psalm XVI, 2, but this time without l'vovyi. The corresponding texts in the Skaryna Psalter have skimen and skimen l'vov respectively. In the recent Russian version the word lev is used throughout.

2) The word kaldor is of considerable interest both from the lexical and morphological point of view, on account of its suffix. It does not appear to be recorded in any dictionary, either 'ordinary', or etymological. The word corresponds to the Hebrew gat meaning 'a place excavated in the earth or rock for the treading of grapes or other agricultural products' (Latin torcular). It is found in Codex 262 in the expression Kaldor toptal adonai děvce dočcě ihudinoi (Lam.

8. See A. Bachańkoū, M. Hajdukievič, P. Šuba, Ttumačalny słoūnik biełaruskaj movy, Minsk, 1966, p. 122. The word kožan is also recorded by Dal', op. cit., II, p. 327, Vasmer op. cit., II, p. 277, and A. Preobrazenskij, Etimologiceskij slovar' russkogo jazyka, Moscow, 1910-14, I, p. 329. According to Dal' (loc. cit.) the term is archaic and comes from the western and southern regions (i. e. Byelorussia and the Ukraine). Vasmer sees a possible etymological link between the name kožan and the word koža - 'skin'. 
I, 15), which is a literal translation from the Hebrew. In the King James Bible the translation is somewhat freer: 'The Lord hath trodden the virgin, the daughter of Judah, as in a wine press'. The other East Slavonic versions, either contemporary with, or later than, Codex 262 translate the Hebrew gat by točilo, e.g.: Točilo točil est Hospod' devici dščere Iudine (Skaryna); Točilo izbra G(ospo)d' d(ě)vicy dsceri ioudině (Ostrog Bible); Točilo istopta G(ospo)d' dèvicě dsceri iudinoj (Synodal Bible). Also the new Russian Bible has Kak $v$ točile istoptal devu, doč Iudy.

Early Polish Bibles use the word prasa from the German Presse, e.g. Prase deptat Pan pannie, córce Judzkiej (Wujek's version of 1599), Pan tłoczyt jako $w$ prasie panne, córke Juclzka (Protestant version of 1632). In the most recent Biblia Millenii, the word prasa is changed to tlocznia: Pan, jak $w$ tłoczni podeptal dziewice, córę Judy. The Czech Kralická Bible (1613) has Tlačil Pan presem pannu dcem judsku. In the Croat translation by Daničić it reads kao groždie u kaci izgazi Gospodin djevkoju kćer Judinu, and in the 1968 version $U$ tijesku izgazi Gospod mene, djevicu kćerku Judinu.

The word kaldor - provided the suffix -or is not a mistake of the copyist - is no doubt related to the Byelorussian katdobina, meaning 'furrow, hole filled with water'. It also exists in Russian dialects under the forms kaldoba, kaldobina, koldobina as attested by Dal', Preobraženskij and Vasmer ${ }^{9}$. Sławski sees a possible connection between katdobina and Polish kadtub. ${ }^{10}$

While refraining from any rash attempt to give an etymological explanation of the word kaldor, it is worth pointing out that its use in the Byelorussian Codex 262 helps towards a better understanding of this and other East Slavonic words belonging to the semantic group in question.

3) Protož ijudejane ottvoristy (sic!) što sedjat $v$ horodech otvorenych (Esther IX, 19). The King James Bible has: 'Therefore the Jews of the villages, that dwell in the unwalled towns'.

The word otvoristy occurs only in Codex 262 and is a literal and faithful translation of the Hebrew haperāzìm. ${ }^{11}$ The same passage in Skaryna's version reads: No tyi iudei iže vo inych mestach $i$ selach byša, etc. Skaryna, probably following his Czech model, does not translate the word haperāzìm at all.

In an earlier translation of the Book of Esther, ${ }^{12}$ preserved in several manuscripts from the 14th century onwards (e.g. in the 15th

9. Dal', op. cit., II, p. 77; Vasmer, op. cit., II, p. 287; Preobraženskij, op. cit., I, p. 285.

10. Fr. Sławski, Stownik etymologiczny jezzyka polskiego, Cracow, 1952, II, pp. 16-17.

11. According to the corrected — the so-called qeri — reading, instead of the incorrect haperāwozim found in the text.

12. On the problem of the authorship of this translation as well as the original from which it was translated see N. A. Meščerskij, 'K voprosu ob izučenii perevodnoj pis'mennosti Kievskogo perioda', Vcenye zapisky Karelo-Finskogo Pedagogiceskogo Instituta, II, 1, 1955, pp. 198-219. The article gives an extensive bibliography of the subject. 
century manuscript 2 (2027), formerly from the Troicko-Sergeevskaja monastery, now in the Lenin State Library in Moscow), the word raspraščenici is used in place of otvoristy: Togo radi ijudei raspraščenici iže sédjachu po gradom raspraženym. Sreznevskij gives the following explanation: raspraščenik - vm. rasprašenik - razsejannyj. After having quoted the above-mentioned phrase, he adds in parentheses: $v$ nov. razsejanii; hoi diesparmenoi, dispersi; tak $i v E v r .{ }^{13}$. He is mistaken, however, in his assertion about dispersi and tak $i v E v r$. (i.e. 'similarily in the Hebrew text'). The expression in the Vulgate is qui in oppidis non muratis ac villis morabuntur. Other Catholic versions follow the Vulgate, e.g. Wujek: $C i$ lepak žydowie którzy $w$ miasteczkach niemurowanych i po wsiach. The Hebrew word haperāzìm does not mean 'dispersed', but 'open, not walled in, an inhabitant of an open place'. ${ }^{14}$ Sreznevskij 's remark about raspraščenik and his equating it with the Greek hoi diesparmenoi does not accord well with the general opinion of Russian scholars (with the exception of Sobolevskij) that the abovementioned translation of the Book of Esther was made on the basis of the Masoretic text. ${ }^{15}$ How can one explain this literal dependence on the Septuagint? Such dependence is also evident in the later Synodal version (the quotation is taken from the 1856 edition): Iudei razsějannii vo vsjakoj straně vněšnej. In the Ostrog Bible chapter IX of the Book of Esther ends on verse 16, and thus the verse in question is missing.

Thus, if the hypothesis of a Hebrew basis for the Slavonic translation of the 'Muscovite' text of the Book of Esther is retained, it is necessary to reject Sreznevskij's remark about the word raspraščenik, in which he equates it with rasprašenik. One should accept rather the reading of the Codex RKF-52 in the Central Library of the Lithuanian Academy of Sciences in Vilna: Togo radi ijudei rasprja ̌̌čanicy iže sédjachu po gradom rasprašenym; it is possible that rasprjaščanici (singular suffix -anik) is a deverbalised derivative from *raspręti (stem *pręg), which is nearer to the Hebrew haperāzkìm than Sreznevski's rasprašenik.

Reverting to the word otvoristy, it is, as has already been said, a literal translation of the Hebrew haperāzimm. ${ }^{16}$ Its formation by means

13. I. Sreznevskij, Materialy dlja slovarja drevne-russkogo jazyka, III, StP., 1903, p. 81.

14. The new Hebrew-Russian dictionary has: perāzìi: neukreplennyj (napr. o gorode); perāzōt, 'ir perazot': gorod bez krepostnoj steny (Ivritrusskij slovar', Moscow, 1963, p. 503).

15. Meščerskij has this to say about the author of the translation and its original text: 'I tak, perevod, nesomnenno, sdelan neposredstvenno $s$ evrejskogo originala, pričem perevodčikom, dlja kotorogo russkij jazyk byl bliže i ponjatnee, čem jazyk evrejskij' (Meščerskij, op. cit., p. 211).

16. According to the Hebrew Biblical exegesis. The renowned exegete Rashi (Rabbi Shelomo Yitshaki, 1040-1105) provides the following comments on this point: 'Haperāzim (are those) Who do not dwell in walled cities'. On the characteristic features of the Biblical exegesis in the Byelorussian Codex 262, see M. Altbauer, 'Traces of Hebrew Commentaries in the Slavonic Translations of the Bible' (in Hebrew with a summary in English), Tabriz, Jerusalem, 1965, pp. 379-81 \& IX-X. 
of the suffix -ist-yj, which is productive and quite common in the East Slavonic languages, is clear and presents no difficulties. ${ }^{17}$

The word otvoristyi is not recorded in any of the East Slavonic dictionaries (Dal', Sreznevskij, Ušakov). It was known, on the other hand, in 16th century Polish, and was recorded in dictionaries such as the Latin-Polish dictionary of Jan Maczyński of $1564^{18}$ and PolishLatin dictionary of Bartoiomiej of Bydgoszcz of 1532 (publ. by B. Rzepka, Poznań, 1900). ${ }^{19}$ It also appears in Bible translations, e.g. in Wujek: jako miasto otworzyste a bez murów (Prov. XXV, 28), as compared with miasto rozwalone bez murów in the Gdańsk Bible. In the Slavonic Synodal version (ed. 1858) the same passage reads jakoze grad stenami razoren $i$ ne ogražden, while the new Russian translation has čto gorod razrušennyj bez sten. The Byelorussian version of Codex 262, horod prolomlenyi bez mura, faithfully renders the Hebrew original 'ir per $\bar{u} c \bar{a}$ (not perūuzā!) èn hōmā.

Linde in his dictionary, having recorded several meanings of otworzysty, compares it with Russian otverstyj.

The faithful adherence to the Hebrew original in the Byelorussian Codex 262 is not limited to the word haperāzim of Esther IX, 19. The same applies to the word perāzōt in the expression be'ârei hape$r \bar{a} z \bar{o} t$ in the same verse, which in the Byelorussian translation becomes $v$ horodech otvorenych. In this, Codex 262 differs again from earlier Slavonic translations, as well as from the Synodal version. Only the new Russian translation comes nearer to the original: Poetomu Iudei živuščie v selenijach otkrytych. The new Ukrainian version (publ. by Brit, and Foreign Bible Soc.) is not literal: Z tie] pričiny judex sil'ski, ščo živut' po silach ta prisilkach. Also non-literal is the translation in the Hebrew-Russian edition of the Book of Esther by J. I. Pirožkov (Vilna, 1903): Poetomu Iudei oblastny e, živuščie $v$ gorodach oblastnych. On the other hand O. N. Steinberg in his Russian translation of the Pentateuch gives an exact translation of the Hebrew expression 'ârei haperāzì (Deut. III, 5): vse eti goroda, krome gorodov otkrytych. In the Synodal version the same expression is do vesi Ferzeovy, as if haperāzi were a proper name. This mistake was made under the influence of the Septuagint which has left the Hebrew word

17. See K. Atrachovič, M. Bułachaū (eds.), Hramatyka biełaruskaj movy, I, Minsk, 1962, pp. 204-5; Grammatika russkogo jazyka, I, Moscow, 1960, p. 330; also I. S. Morkur'eva, 'Slovoobrazovanie kačestvennych imen prilagatel'nych v russkim jazyke XI-XVI v. (Suffiksy s primetoj '-t-')', Učenyje Zapiski (Leningr. Pedagog. Inst. im. A. I. Hercena, Kafedra russkogo jazyka), 144, Leningrad, 1958, pp. 117-44. (See in particular pp. 134-36 about the suffix -ist. Among the examples in the article the word otvoristyj is not mentioned.)

13. Quoted from W. Kuraszkiewicz, Wyrazy polskie $w$ stowniku tacińskopolskim Jana Mączyńskiego. Część I: A-O, Wrocław, 1962, p. 288, column 2.

19. Quoted from St. Respond, Studia nad językiem polskim XVI wieku, Wrocław, 1949, pp. $129 \& 203$. 
untranslated: ${ }^{20}$ plēn tōn poleōn tōn ferezaiōn. ${ }^{21}$ The Vulgate translates the text correctly: absque oppidis innumeratis, quae non habebantmuros. In the new Russian Bible the mistake of the Synodal version has been corrected: Krome gorodov neukrep lennych. Similarly the new Ukrainian version (1949) has okrim mist neukreplennych.

The question arises as to whether the author of Codex 262 in his attempt at a literal translation ${ }^{22}$ of the Bible found the word otvoristy in the contemporary Byelorussian language, or whether he made a borrowing from the Polish. The present writer, having no access to the necessary material, is unable to solve this problem. It should be noted, however, that the language of Codex 262 is on the whole free from Polish lexical borrowings, and that it was written long before the appearance of the first Polish printed Bible.

It has been pointed out at the beginning of this article that the Byelorussian biblical texts in Codex 262 contain much interesting material for Byelorussian, and general East Slavonic, lexicology. It is to be hoped that the concordance of these texts, which is in the course of preparation by the present writer, as an appendix to the Codex 262 which is to be published in the near future by the Israeli Academy of Sciences, will contribute to the extension of our knowledge of the vocabulary of Byelorussian and other East Slavonic languages in the 15-16th centuries.

20. This is not an uncommon occurrence in the Septuagint. For another example of this (about the untranslated word to felomouni in LXX in Dan. VIII, 13) see Altbauer, 'Traces' (see above, note 16).

21. Also in 1 Sam. VI, 18: krome gradov Ferezejskich. Only in Ezech. XXXVIII, 11 the translation is somewhat more exact: na zemlu otveržennuju, following the Septuagint version epi gèn aperrimmenen. In the Vulgate the same passage reads ad terrain absque muros.

22. See the reference to this kind of translation technique in Eugene A. Nida, Bible Translating. An Analysis of Principles and Procedures, New York, 1947, pp. 11-12 ('Rendering the same Hebrew or Greek word by the same English word'). 